\title{
Bioactive content during the development of the acerola cv. BRS 238 (Frutacor)
}

\author{
Conteúdo de bioativos durante o desenvolvimento da acerola cv. BRS 238 (Frutacor) \\ Contenido de bioactivos durante el desarrollo de la acerola cv. BRS 238 (Frutacor)
}

Received: 02/03/2021 | Reviewed: 02/08/2021 | Accept: 02/13/2021 | Published: 02/21/2021

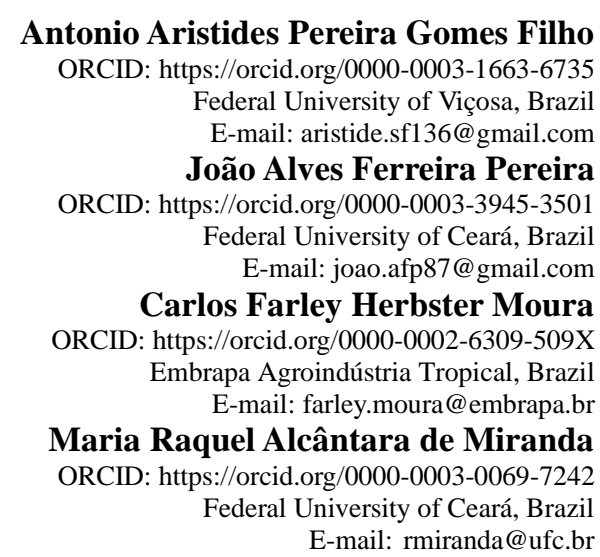

\begin{abstract}
The objective of this work was to determine quality, bioactive content and metabolism of vitamin $\mathrm{C}$ and phenolic compounds during the development of acerola BRS 238 (Frutacor). Fruits were harvested at five different stages of maturation and evaluated for physical-chemical and chemical quality characteristics, as well as for the metabolism of vitamin $\mathrm{C}$ and polyphenols variables. During development, there was an increase in SS/AT ratio, a decrease in chlorophyll content, increase in carotenoids content, and a decline in vitamin $\mathrm{C}$ and polyphenols content, alhhtough of yellow flavonoids and anthocyanins content increased. The enzyme activity of vitamin $\mathrm{C}$ metabolism, ascorbate oxide (AO) and ascorbate peroxidase (APX) decreased with ripening, while for phenolic metabolism, the activity of phenylalanine ammonia lyase (PAL) increased and polyphenoloxidase (PPO) decreased. It can be concluded that the fruits of aceroleira BRS 238 had a high content of bioactive compounds. For industrial extraction of bioactive compounds, fruits must be harvested at the initial stages, while for fresh consumption, they must be harvested in the final stages of development.
\end{abstract}

Keywords: Malpighia emarginata DC; Maturation; Enzyme activity.

\begin{abstract}
Resumo
O objetivo deste trabalho foi determinar caracteristicas de qualidade, o conteúdo de bioativos e a atividade de enzimas do metabolismo da vitamina $\mathrm{C}$ e dos compostos fenólicos durante o desenvolvimento da acerola BRS 238 (Frutacor). Frutos foram colhidos em cinco diferentes estádios de maturação e avaliados quanto as características físico-químicas e químicas de qualidade, assim como para o metabolismo de vitamina C e de polifenóis. Durante o desenvolvimento desses frutos houve um aumento na relação SS/AT, uma queda no conteúdo de clorofila, aumento no conteúdo de carotenoides, um declínio no conteúdo de vitamina $\mathrm{C}$ e polifenóis, todavia o conteúdo de flavonoides amarelos e antocianinas aumentaram. A atividade das enzimas do metabolismo da vitamina C, ascorbato oxidade (AO) e peroxidase do ascorbato (APX) diminuíram com o amadurecimento, enquanto para o metabolismo fenólicos, a atividade da fenilalanina amônia liase (PAL) aumentou e da polifenoloxidase (PPO) reduziu. Pode-se concluir que os frutos da aceroleira BRS 238 apresentaram alto conteúdo de compostos bioativos. Para extracção industrial e bioativos, esses frutos devem ser colhidos no estádio inicial, enquanto para consumo in natura, devem ser colhidos nos estádios finais do desenvolvimento.
\end{abstract}

Palavras-chave: Malpighia emarginata DC; Maturação; Atividade enzimática.

\section{Resumen}

El objetivo de este trabajo fue determinar las características de calidad, contenido de bioactivos y metabolismo de la vitamina C y compuestos fenólicos durante el desarrollo de la acerola BRS 238 (Frutacor). Las frutas se cosecharon en cinco etapas diferentes de maduración y se evaluaron las características de calidad físico-químicas y químicas, así como el metabolismo de la vitamina $\mathrm{C}$ y los polifenoles. Durante el desarrollo de estos frutos hubo un aumento en la relación SS / AT, una disminución en el contenido de clorofila, un aumento en el contenido de carotenoides, una disminución en el contenido de vitamina $\mathrm{C}$ y polifenoles, mientras el contenido de flavonoides amarillos y las 
antocianinas aumentaron. La actividad enzimática del metabolismo de la vitamina $\mathrm{C}$, oxidasa de ascorbato (AO) y la peroxidasa de ascorbato (APX) disminuyaran con la maduración, mientras que para el metabolismo fenólico, la actividad de la fenilalanina amoniaco liasa (PAL) aumentó y la polifenoloxidasa (PPO) disminuyó. Se puede concluir que los frutos de aceroleira BRS 238 tuvieron un alto contenido de compuestos bioactivos. Para la extracción industrial y bioactiva, estos frutos deben cosecharse en la etapa inicial, mientras que para el consumo fresco, deben cosecharse en las etapas finales de desarrollo.

Palabras clave: Malpighia emarginata DC; Maduración; Actividad enzimática.

\section{Introduction}

Brazil is the world's largest producer, exporter and consumer of acerola as it is produced in all regions although, mainly on the Northeast region where it found the most favorable conditions for development. In this region, Pernambuco state stands out as the largest producer (Anuário da Agricultura Brasileira [AGRIANUAL] (2019); Calgaro \& Braga, 2012; Instituto Brasileiro de Geografia e Estatística [IBGE] (2018); Ritzinger \& Ritzinger, 2011).

The first varieties propagated vegetatively in the northeast of Brazil were Flor Branca, Okinawa and Sertaneja (Ritzinger \& Ritzinger, 2011). Ever since, great advances have been made towards the development of new varieties such as Cabocla, Rubra, Tropicana, Morena, Mulata, Apodi, Cereja, Frutacor, Roxinha and Jaburu, which besides being rich in bioactive compounds and more suitable for use in natura, are more suitable for industrial pulp and juice processing and vitamin C extraction (Ritzinger, 2018).

Acerola is source of several health-promoting components as sugars and organic acids as malic, citric and tartaric acid (Riguetto, Netto, \& Carraro, 2005). However, the main commercial interest of acerola comes from its high ascorbic acid or vitamin $\mathrm{C}$ content as varieties contain from 1,500 to 4,500 mg. 100g- ${ }^{1}$, almost 100 times the concentrations found in citrus fruits (Moreira et al., 2009; Almeida et al., 2014). In addition to the considerable amount of vitamin C, acerola is also good source of phenolic and carotenoid compounds, associated with fruit color besides their antioxidant defense potential (Calgaro \& Braga, 2012; Mariano-Nasser et al., 2017).

Acerola nutritional properties depends upon several factors such as edaphoclimatic conditions, cultural practices, maturity harvesting stage, processing and post-harvest storage (Delva \& Schneider, 2013). Despite the various studies carried out with acerola, there is still a lack of information regarding changes in bioactive metabolism during the development of fruits grown in the state of Ceará. Thus, this work aimed to determine the bioactive content and enzyme activity of the metabolism of vitamin C and phenolic compounds during the development of fruits from BRS 238 (Frutacor) clone produced in Ceará State.

\section{Methodology}

Aceroleira fruits (Malpighia emarginata DC) from cv. BRS 238 (Frutacor) were harvested, in October of 2018, in the experimental field of Embrapa Agroindustia Tropical, located in Pacajus, Ceará. The coordinates of the place are $4^{\circ} 10$ 'S and $38^{\circ} 27^{\prime} \mathrm{W}$ and an altitude of $60 \mathrm{~m}$ above sea level.

Fruits were harvested at different developmental stages (Figure 1): 1) small and green color, 2) large and light green color, 3) large with up to 30\% red color, 4) large with up to 50\% red color and 5) large with up to $100 \%$ red color. After harvest, fruits were selected for uniformity of stage, and absence of injuries, sanitized, pulp was processed using a domestic centrifuge and stored at $-18 \mathrm{oC}$ until analysis of physical-chemical and chemical characteristics and variables of vitamin $\mathrm{C}$ and phenolic metabolism. 
Figure 1 - Acerola developmental stages.
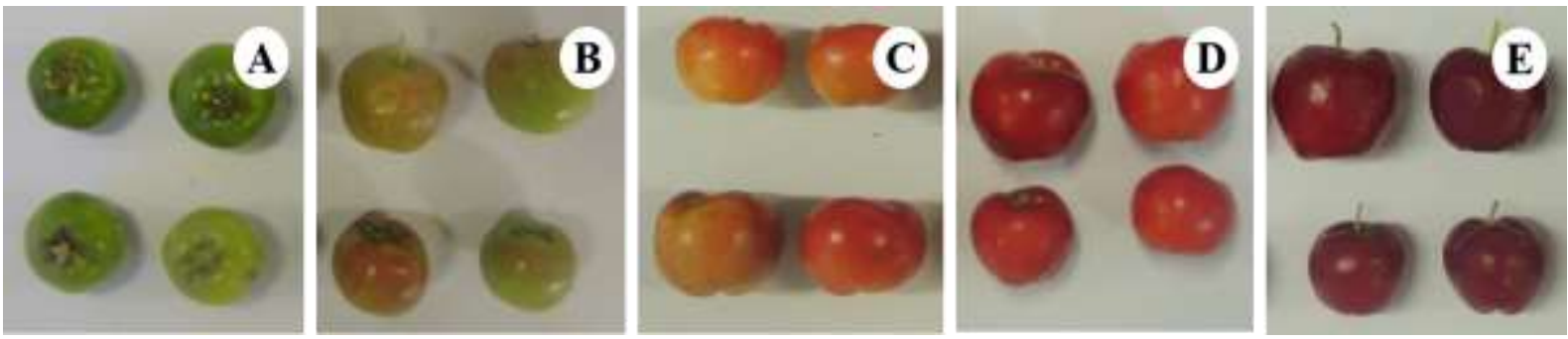

Source: Authors (2020).

\section{Physico-chemical and chemical analysis}

\section{Soluble solids (SS)}

Soluble solids were measured as pulp was filtered using a digital refractometer (KASVI model K52-032), as results were expressed in ${ }^{\circ}$ Brix.

\section{Titratable acidity (AT)}

According to the methodology by Instituto Adolfo Lutz [IAL] (1985), $1.0 \mathrm{~g}$ of pulp was diluted in $50 \mathrm{~mL}$ of distilled water and titrated with a $\mathrm{NaOH}$ solution $(0.1 \mathrm{M})$, with $1 \%$ phenolphthalein as an indicator. The basic solution was added slowly until color changed to pink and results were expressed as a percentage of malic acid.

pH

$\mathrm{pH}$ was measured directly on the fruit pulp using a digital pHmeter, according to Association of Official Agricultural Chemists [AOAC] (2005).

\section{Chlorophyll and carotenoids}

Chlorophyll and carotenoids were determined according to Lichtenthaler and Wellburn (1983), with adaptations. $1.0 \mathrm{~g}$ of fresh pulp was vortexed for $30 \mathrm{~s}$ with $1 \mathrm{~mL}$ of $80 \%$ acetone $(\mathrm{v} / \mathrm{v})$ and $0.1 \mathrm{~g}$ of calcium carbonate then, centrifuged at $3000 \mathrm{x}$ $\mathrm{g}$ for $15 \mathrm{~min}$ at room temperature. The supernatant was collected $(300 \mu \mathrm{L})$ and absorbance were measured at 663, 646 and 480 $\mathrm{nm}$ in a microplate reader (Synergyx Mx, Biotek, USA). Results were expressed in mg.kg-1 and calculated as following:

- Chlorophy a $(\mathrm{mg} / \mathrm{mL})=12,21 \times(\mathrm{A} 663)-2.81 \times(\mathrm{A} 646)$

- Chlorophyll b $(\mathrm{mg} / \mathrm{mL})=20.13 \times(\mathrm{A} 646)-5.03 \times(\mathrm{A} 663)$

- Carotenoids $(\mathrm{mg} / \mathrm{mL})=(1000 \times$ [A470] - $3.27 \times$ [Chlorophyll a] - $104 \times$ [Chlorophyll b] $) / 229$

\section{Total soluble proteins}

The content of total soluble proteins was determined according to Bradford (1976) using bovine serum albumin as a standard (BSA).

\section{Vitamin C metabolism}

\section{Total, reduced and oxidized vitamin $\mathrm{C}$}

Total, reduced (AsA) and oxidized (DHA) vitamin C forms were measured as proposed by Chen and Wang (2002), with modifications. $0.1 \mathrm{~g}$ of pulp was homogenized with $25 \mathrm{ml}$ of $5 \%$ trichloroacetic acid (TCA) in an ice bath. Subsequently, the samples were centrifuged (Sigma 2-16 KL) at 15,000 x g for $12 \mathrm{~min}$ at $4{ }^{\circ} \mathrm{C}$. The supernatant was separated and used as 
extract for the determination of total, AsA and DHA vitamin C forms.

For AsA quantification, $50 \mu \mathrm{L}$ of the extract, $12.5 \mu \mathrm{L}$ of the $100 \mathrm{mM}$ potassium phosphate buffer (pH 7.7), $175 \mu \mathrm{L}$ of solution containing 10\% trichloroacetic acid (TCA), phosphoric acid, 2, 2-bipyridyl and 0.3\% iron trichloride were incubated at $37^{\circ} \mathrm{C}$ for $60 \mathrm{~min}$ and then absorbance was monitored at $525 \mathrm{~nm}$.

For total vitamin $\mathrm{C}$ quantification, $50 \mu \mathrm{L}$ of the extract, $25 \mu \mathrm{L}$ of $100 \mathrm{mM}$ potassium phosphate buffer $(\mathrm{pH} 7.7)$ and $12.5 \mu \mathrm{L}$ of $0.01 \mathrm{mM}$ dithiothreitol (DTT), $175 \mu \mathrm{L}$ of solution containing $10 \%$ TCA, 8.8\% phosphoric acid, $0.8 \%$ 2,2-bipyridyl and $0.3 \%$ iron trichloride were maintained at $37^{\circ} \mathrm{C}$ for $60 \mathrm{~min}$ and the, absorbance was measured at $525 \mathrm{~nm}$. DHA content was calculated as difference between total vitamin $\mathrm{C}$ and AsA contents. A standard curve of ascorbic acid was used to calculate the analyzes and the results were expressed in mg.kg-1.

\section{Ascorbate Oxidase Activity (AO, EC 1.10.3.3)}

Extraction was prepared according to Cardello and Cardello (1998) and activity was determined according to Bergmeyer, Grassl and Walter (1983). Specific enzyme activity was calculated using the molar extinction coefficient $(\varepsilon=10$ $\mathrm{mM}-1 . \mathrm{cm}-1)$ and the results expressed in $\mu$ mol AsA.min-1.mg-1 of proteins (P).

\section{Ascorbate Peroxidase Activity (APX, EC 1.11.1.11)}

Extraction was prepared accoridn to Yang, Zheng and Cao (2009 and activity was determined according to Nakano and Asada (1981). Specific enzyme activity was calculated using the molar extinction coefficient $(\varepsilon=2.8 \mathrm{mM}-1 . \mathrm{cm}-1)$, the results being expressed in $\mu$ mol $\mathrm{H} 2 \mathrm{O} 2$. min-1.mg-1 P, considering that 1 mol of AsA is necessary for the reduction of $1 \mathrm{~mol}$ of $\mathrm{H} 2 \mathrm{O} 2$.

\section{Phenolic Compounds Metabolism \\ Total extractable polyphenols (TEP)}

Extract was obtained according to Larrauri, Ruperez and Saura-Calixto (1997) and total polyphenol content was determined by Folin-Ciocalteu method (Obanda, Owuor, \& Taylor, 1997) adapted by Rufino et al. (2007). The content of TEP was calculated based on a standard curve of increasing doses of $98 \%$ gallic acid $(0-50 \mu \mathrm{g})$, used as a reference and the results expressed in mg of gallic acid equivalents (EAG) .kg-1.

\section{Yellow flavonoids and total anthocyanins}

Yellow flavonoids and total anthocyanins was determined as described by Francis (1982), calculated using molar extinction coefficient 76.6 and 98.2 mol-1.cm-1, respectively, and results were expressed in mg.kg-1.

\section{Phenylalanine ammonia lyase activity (PAL, EC 4.3.1.24)}

Enzymatic extract was prepared according to Mori, Sakurai and Sakuta (2001) and El-Shora (2002), while activity was based on a curve using transcinamic acid as standard and results were expressed in $\mu$ mol transcinamic acid.h-1.mg-1 P.

\section{Polyphenoloxidase activity (PPO, EC 1.14.18.1)}

Enzymatic extract was prepared according to Sojo, Nuñes-Delicado and García-Carmona (1998), while activity was determined acas Robinson (1987). Na activity unit (AU) was defined as a variation of 0.001 in the absorbance of the mixture at $395 \mathrm{~nm}$ and the results were expressed as min-1.mg-1 P. 


\section{Experimental design and statistical analysis}

The experimental design adopted was the completely randomized design with five treatments and three repetitions. The data were subjected to analysis of variance (ANOVA) and the comparison of means performed using the Tukey test at the level of 5\% probability using the statistical software SISVAR, version 5.6.

\section{Results and Discussion}

\section{Physico-chemical and chemical analysis during the development of acerola BRS 238}

Soluble solids (SS) content of acerola BRS 238 increased signficantly during ripening (Figure 2). At stage 2, the SS content was at $9.5^{\circ}$ Brix and it increased significantly to $11^{\circ}$ Brix at stadium 5. Ribeiro and Freitas (2020) found values that SS increased from 7.6 to $8.6^{\circ}$ Brix during maturation of cv. Junko. Figueiredo Neto et al. (2014) studying the cv. Flor-Branca, Okinawa and Sertaneja found the highest SS contents for ripe acerola cv. Okinawa, $12.70{ }^{\circ}$ Brix. The increase in SS content can be explained, mainly by the accumulation of sugars through gluconeogenesis or the hydrolysis of polysaccharides such as starch (Oliveira, 2012).

Figure 2 - Soluble solids (SS) content during development of acerola BRS 238. Different letters represent signficant difference by Tukey's test at $5 \%$.

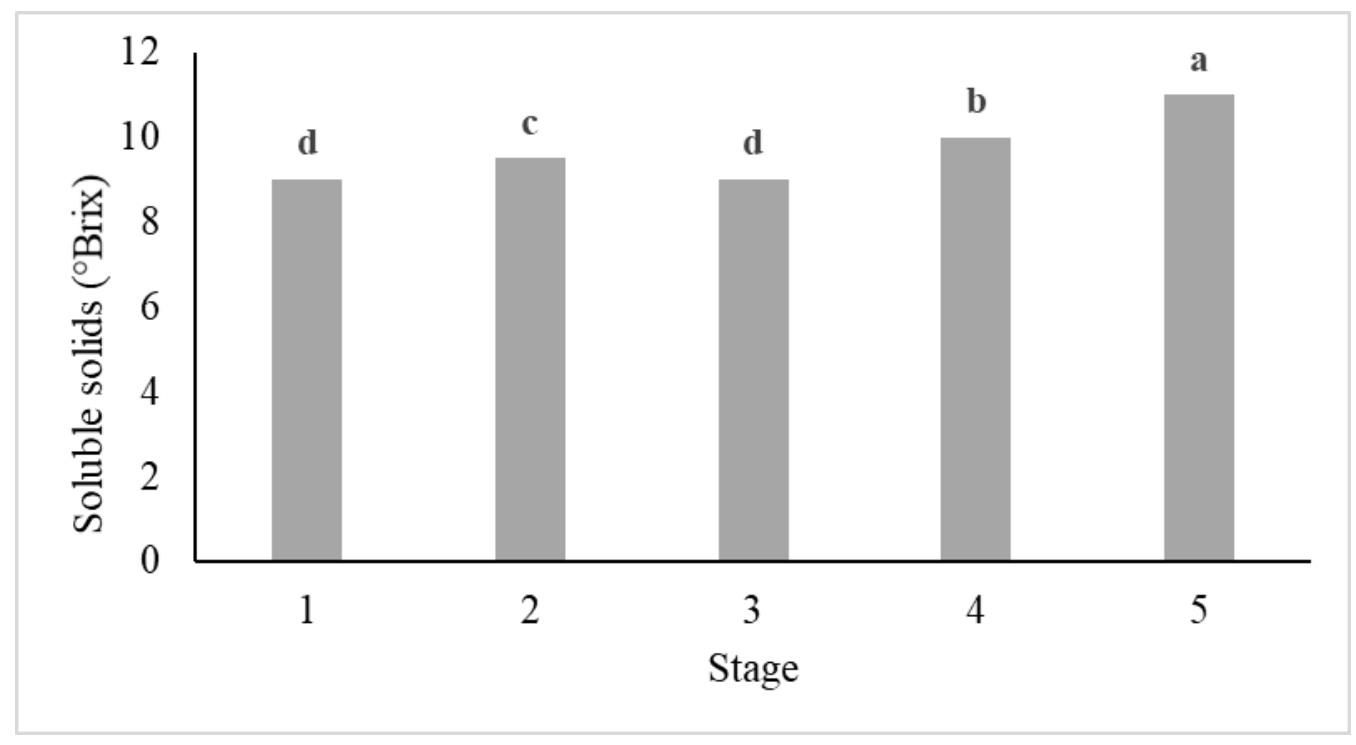

Source: Authors (2020).

In order to have a better understanding of changes in flavor during ripening, titratable acidity (TA) was also evaluated (Figure 3). In stage 1, AT was $1.73 \%$ and dropped significantly to $1.27 \%$ malic acid in stage 5. Souza, Moura, Brito and Miranda (2014) studied acerolas from cultivars Flora Sweet, Flor Branca and BRS 366 and observed a decline in acidity with ripening. The values found for TA can vary not only between cultivars and maturation stages, but also in relation to different harvest seasons. The observed drop in acidity may have been due to the organic acids used in the Krebs cycle during the respiratory process and as a carbon source for gluconeogenesis or new sugar synthesis (Maciel, Melo, Lima, Souza, \& Silva, 2010). 
Figure 3 - Titratable acidity (TA) during development of acerola BRS 238. Different letters represent signficant difference by Tukey's test at $5 \%$.

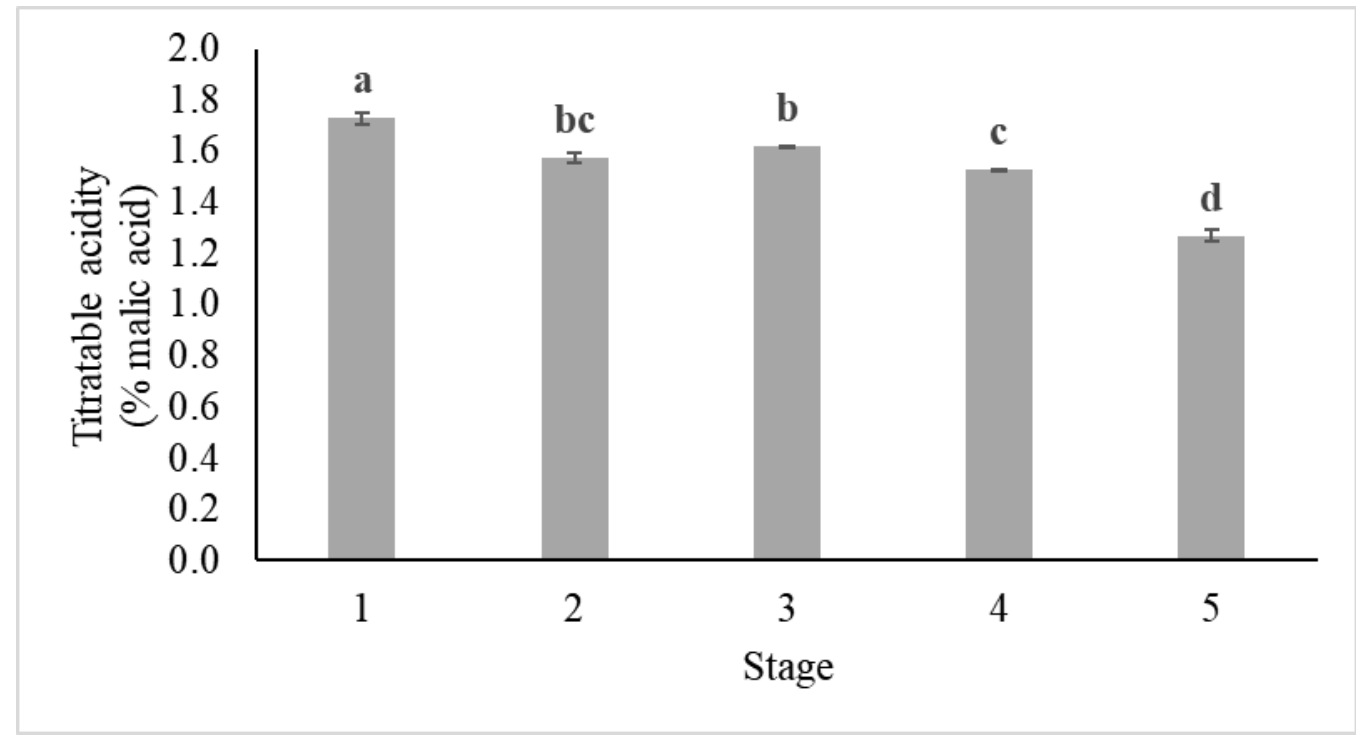

Source: Authors (2020).

As taste results from the relation between SS and TA, this relationship SS/TA (Figure 4) was assessed and increased significantly from 5.21 in stage 1, to 8.67 in stage 5, indicating ripe acerolas still present an acidic flavor. Viana et al. (2017) studied ripe fruits of four organically produced cultivars and observed SS/TA values of 11.66 for cv. Rubra and 4.94 for cv. Junco.

Figure 4 - SS/TA ratio during development of acerola BRS 238. Different letters represent signficant difference by Tukey's test at $5 \%$.

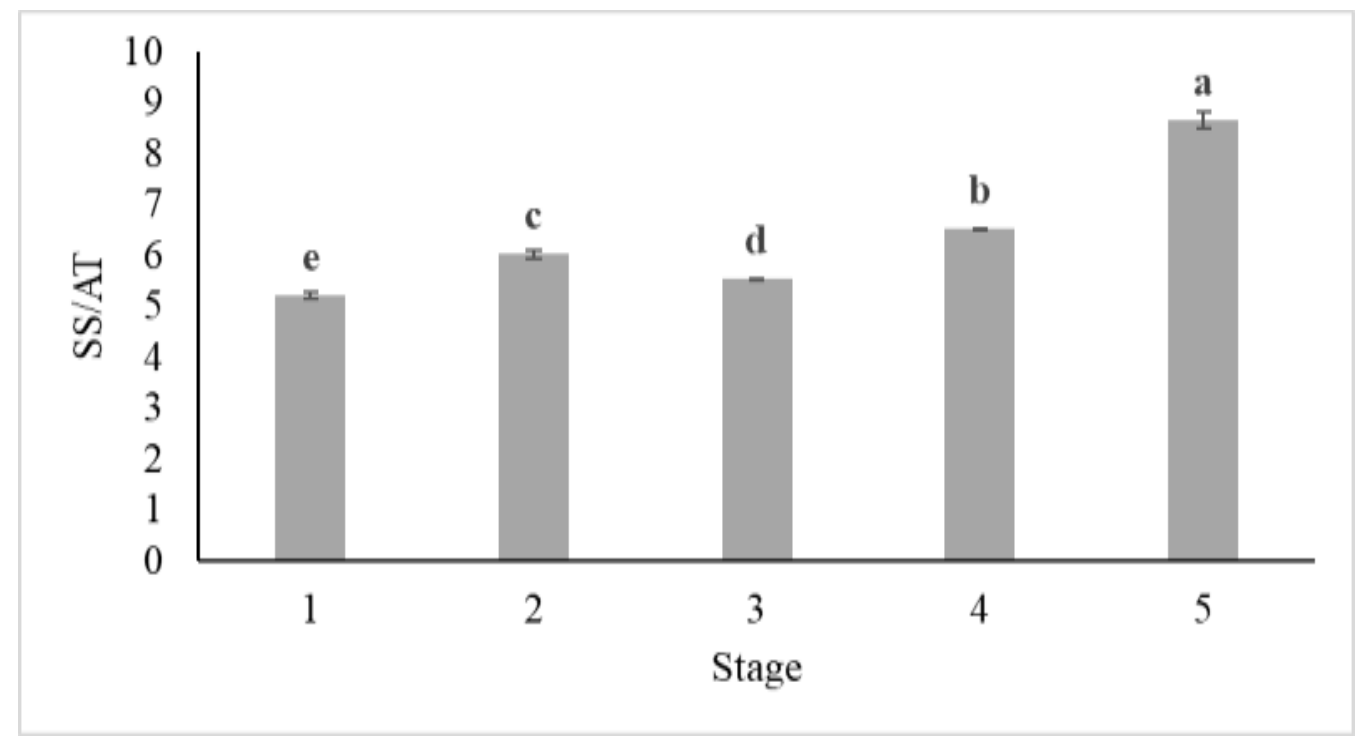

Source: Authors (2020).

$\mathrm{pH}$ value increased signficantly from 3.10 at stage 1 to 3.17 at stage 5 (Figure 5), in agreement with the decline observed in titratable acidity. According to Santos, Vasconcelos, Oliveira, Clemente and Costa (2012), pH is mostly stable as fruit maintain constant conditions in their cells cytoplasm for their metabolism. 
Figure 5 - pH during development of acerola BRS 238. Different letters represent signficant difference by Tukey`s test at $5 \%$.

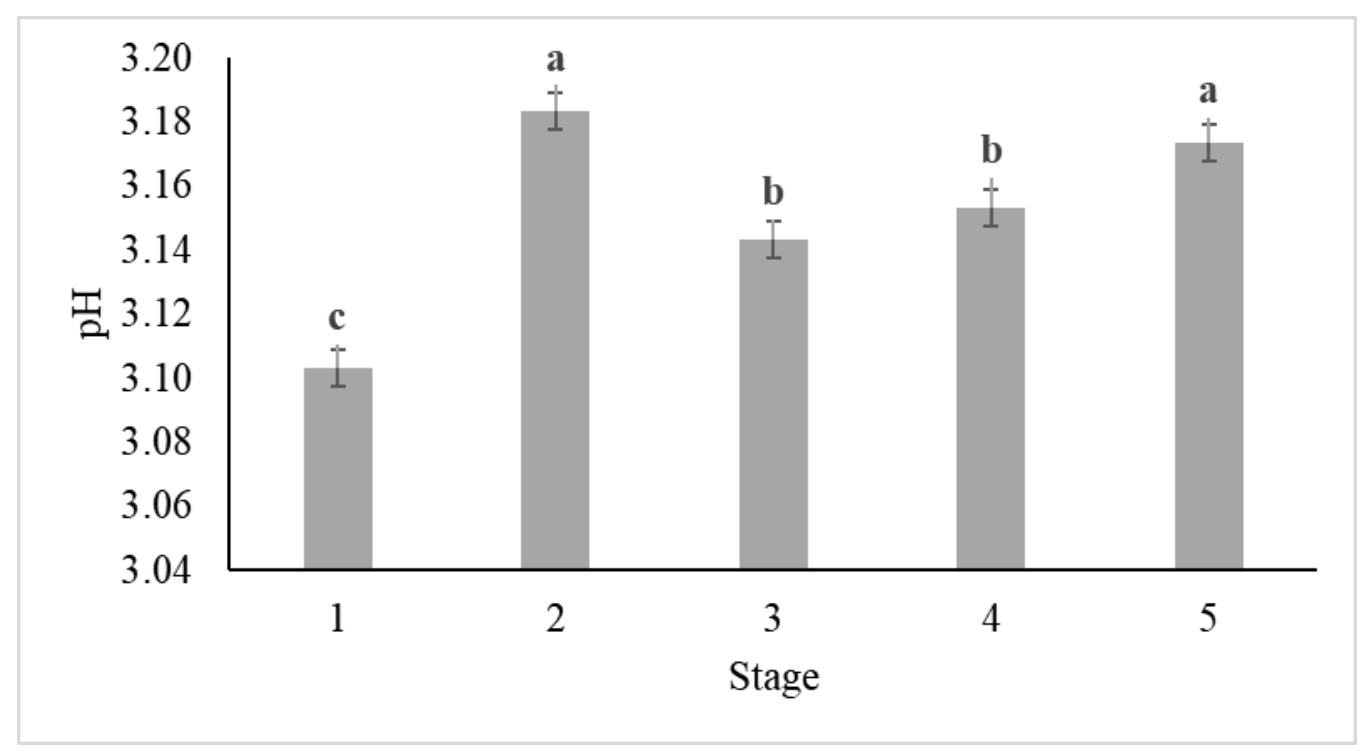

Source: Authors (2020).

Pigments chlorophyll $\mathrm{a}$ and $\mathrm{b}$ and carotenoids changed during acerola devopment (Figure 6). Chlorophyll was gradually degradated, while carotenoids increased. Chlorophyll a content in stage 1 was 357.88 and declined significantly to 27.77 mg.kg-1 in stage 5, while chlorophyll b decline was slower from stage 1 to 5, from 200.30 to $82.32 \mathrm{mg} . \mathrm{kg}-1$, respectively. Carotenoids increased significantly from 8.23 in stage 1 to 127.85 mg.kg-1 in stage 5 , however the main increase was observed after stage 4 . The results of this work indicate that the synthesis of carotenoids in acerola BRS 238 is concomitant with the degradation of chlorophyll, explaining the color change of fruits from green to red. Lima et al. (2005) evaluated acerolas at different maturity stages and reported that carotenoid content varied between 3.2 to $406 \mathrm{mg} . \mathrm{kg}-1$ depending on the genotype, maturity stage harvest time. Carotenoids are important for human nutrition as they are precursors of vitamin A, moreoveor, they are also potent antioxidants, which characterizes it as a bioactive compound (Delgado-Vargas, Jiménez, \& Paredes-López, 2000; Uenojo, Maróstica Junior, \& Pastore, 2007). 
Figure 6 - Chlorophyll and carotenoid during development of acerola BRS 238. Different letters represent signficant difference by Tukey's test at $5 \%$.

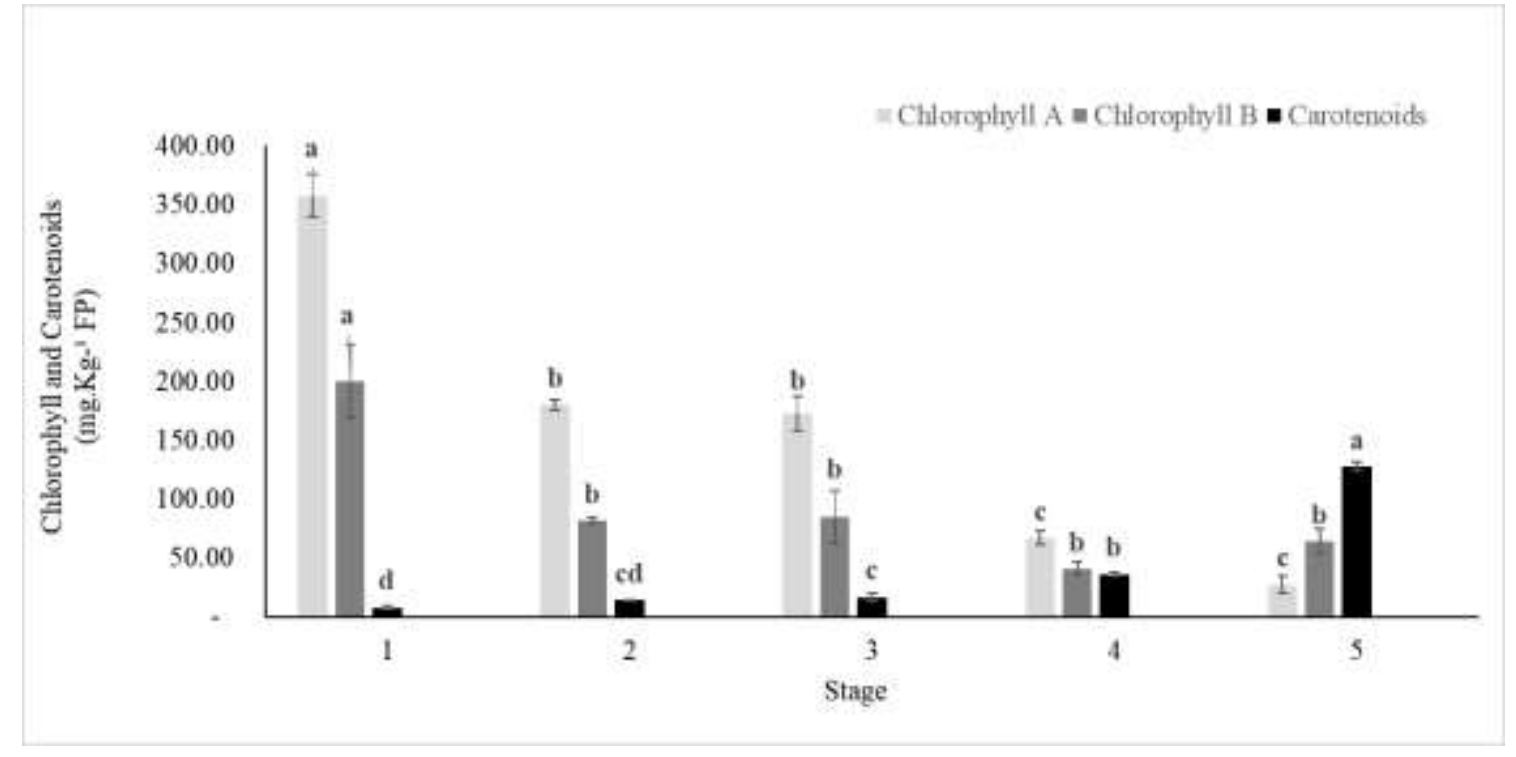

Source: Authors (2020).

\section{Vitamin C metabolism during the development of acerola BRS 238}

Total vitamin C significantly reduced its content from 32,425.29 mg.kg- ${ }^{1}$, in stage 1 to $20,106.10 \mathrm{mg} \cdot \mathrm{kg}-{ }^{1}$ in stage 5 (Figure 7), as well as the reduced (AsA) and oxidized (DHA) forms from 30,294.40 and 2,130.89 to 19,215.33 and 890.77 mg.kg-1 ${ }^{1}$, respectively. Moreover and despite the decline observed, acerola BRS 238 still presents considerably high vitamin C levels. Vitamin C is a bioactive compound that presents human health benefits in both reduced AsA and oxidized DHA forms and its contents vary according to variety, cultivation and harvest conditions, in addition to maturity (Gomez \& Lajolo, 2008; Rabelo, 2016).

Figure 7 - Total vitamin C, ascorbic acid (AsA) and dehydroascorbic acid (DHA) contente during development of acerola BRS 238. Different letters represent signficant difference by Tukey’s test at 5\%.

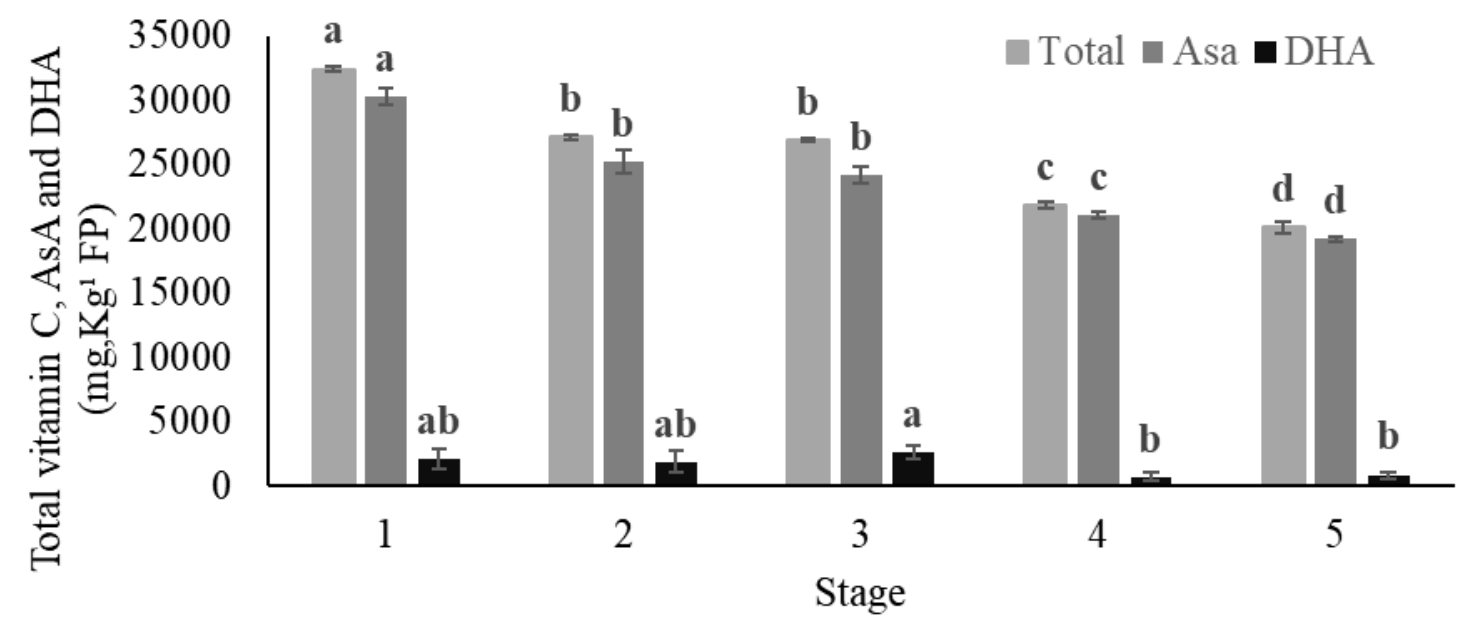

Source: Authors (2020). 
The content and forms of vitamin $\mathrm{C}$ may be influenced by synthesis as well as by degradtion due to enzymatic oxidation or auto-oxidation. Enzymatic oxidation can be mediated by oxidoreductase enzymes such as ascorbate oxidase that catalyzes the oxidation of AsA to monodehydroascorbate (MDHA) by reducing molecular oxygen (O2) to water; and ascorbate peroxidase, which uses two AsA molecules to reduce oxygen peroxide (H2O2) to water, forming MDHA (Foyer \& Noctor, 2011). MDHA may be further oxidized to DHA form.

AO activity peaked at stage 4 reaching $6.62 \mu$ mol AsA.min-1.mg-1 P (Figure 8A), while APX activity declined significantly from 0.20 to $0.15 \mu$ mol H2O2. min-1.mg-1 P from stage 3 to 5 (Figure 8B). The increase in AO activity at stage 4 influences significantly the total vitamin C, AsA and DHA contents (Figure 7), while APX exerted a greater influence on stage 3 (Figure 8B). APX is the most important enzyme involved with $\mathrm{H} 2 \mathrm{O} 2$ neutralization, in chloroplasts, and promotes its detoxification through the donation of electrons from the ascorbate that reduce $\mathrm{H} 2 \mathrm{O} 2$ to water, while forming MDHA (Zimmermann \& Zentgraf, 2005).

Figure 8 - Activity of the enzymes ascorbate oxidase (AO) and ascorbate peroxidase (APX) during development of acerola BRS 238. Different letters represent signficant difference by Tukey's test at 5. Means followed by the same letter do not differ statistically by the Tukey test at $5 \%$ probability.

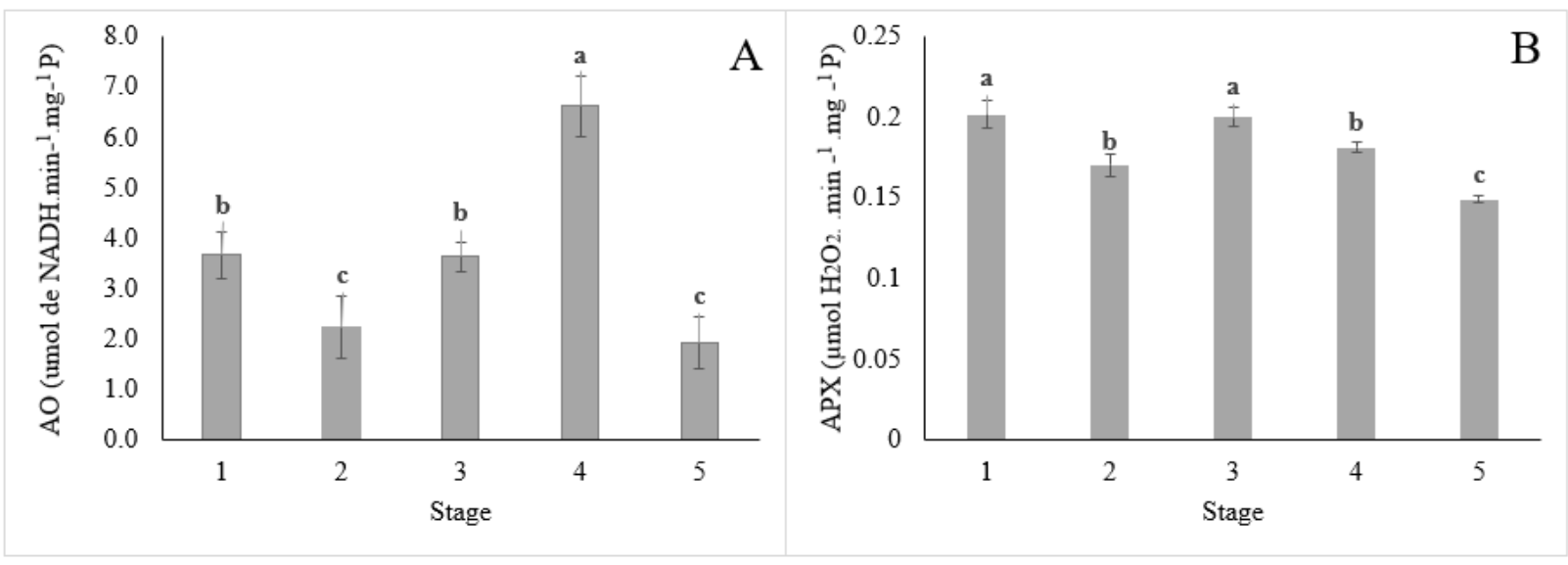

Source: Authors (2020).

\section{Metabolism of phenolic compounds during the development of acerola BRS 238}

Results show that total extractable polyphenols (TEP) decline significantly with fruit development from 50,829.40 mg EAG.kg-1 FP, at stage 3, to 27,900.96 mg EAG.kg-1 $^{1} \mathrm{FP}$, at stage 5 (Figure 9A). Despite the decline observed in phenolics, yellow flavonoid content increased significantly from stage 4 to 5 , from 53.00 to $74.48 \mathrm{mg} \cdot \mathrm{kg}^{-1}$ (Figure 9B), as did the

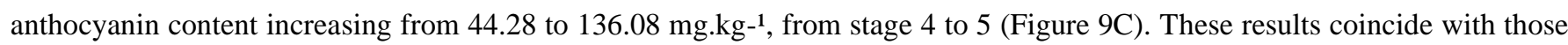
stages when fruits color changed from 75 to $100 \%$ red skin, indicating the greater synthesis of these compounds. 
Figure 9 - Total extractable polyphenols (TEP, A), yellow flavonoids (B) and anthocyanins (C) content during development of acerola BRS 238. Different letters represent signficant difference by $5 \%$.
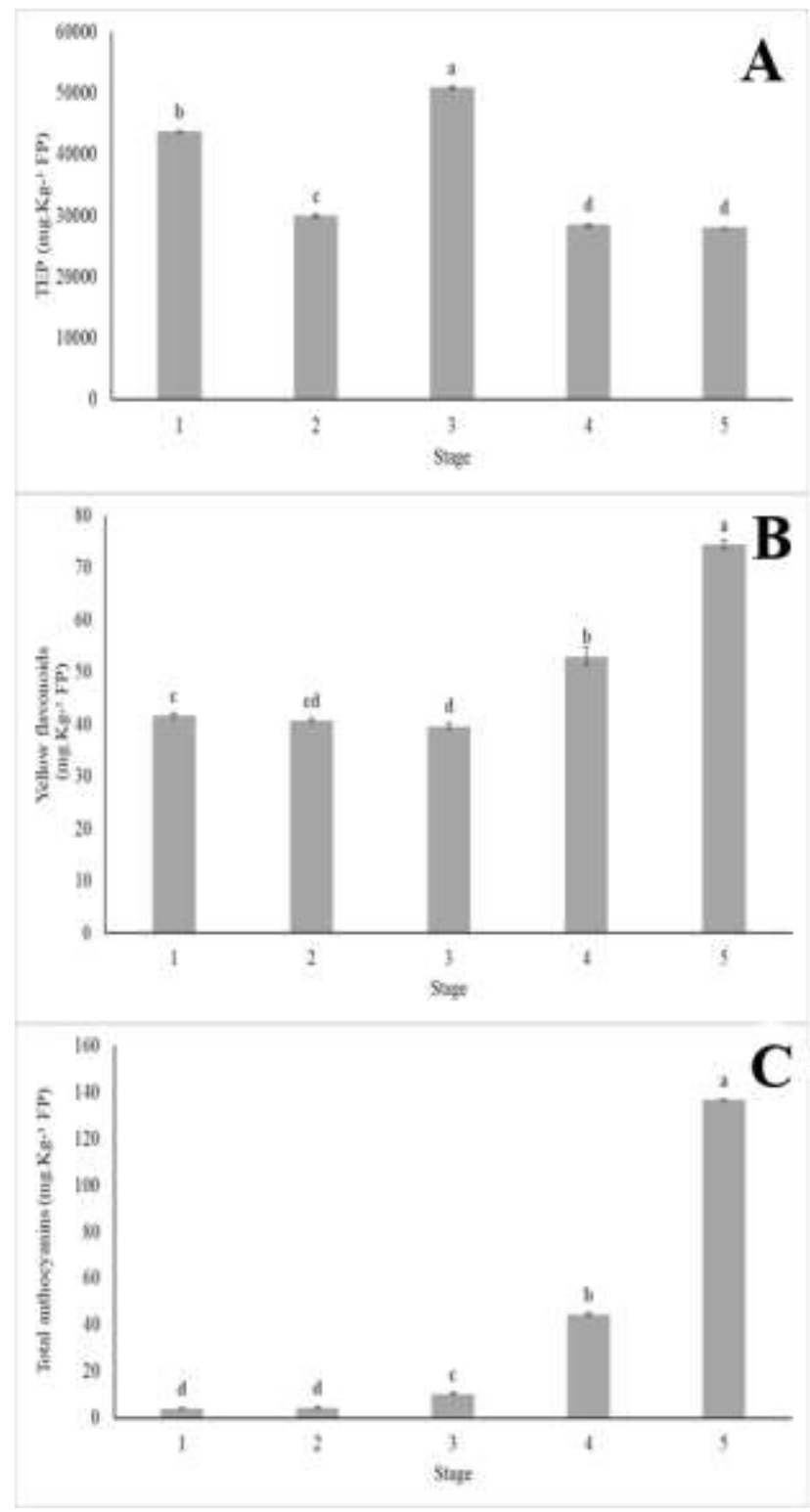

Source: Authors (2020).

Polyphenols, among several other functions, act as antioxidant compounds by suppressing singlet oxygen or free radicals preventing cell damage (Rice-Evans, Miller, Bolwell, Bramley, \& Pridham, 1995; Luo et al., 2011). In general, the antioxidant activity is due to their ability to donate hydrogens from the hydroxyl groups positioned along the benzene ring, in order to prevent the oxidation of lipids and other biomolecules (Foti, Piattelli, Amico, \& Ruberto, 1994; Alamed, Chaiyasit, McClements, \& Decker, 2009). Flavonoids as yellow flavonoids and anthocyanins are phenolic compounds mainly associated with pigmentation of fruits. In addition to physiological functions in plants, they offer health benefits such as anti-allergic, antiviral, anti-tumor, anti-inflammatory and antioxidant functions. (Vendramini \& Trugo, 2004; Huber, Rodriguez-Amaya, 2008; Rodriguez-Amaya, Kimura, \& Amaya-Farfan, 2008).

The content of phenolic compounds depends on the balance between their synthesis and their degradation, and phenylalanine ammonia lyase (PAL) is the main enzyme of its biosynthesis while they can be degradated enzymatically by polyphenoloxidase (PPO) or by self-oxidation. PAL activity increased significantly from stage 1 , with 86.07 to $134.34 \mu \mathrm{mol}$ 
acid. transcin. $\mathrm{h}^{-1} . \mathrm{mg}-^{-1} \mathrm{P}$ at stage 5 (Figure 10A). At stage 3, PAL activity increases significantly concomitantly to TEP content (Figure 9A), indiactive of greater synthesis.

Figure 10 - Phenylalanine ammonia lyase (PAL) and polyphenoloxidase (PPO) activity during during development of acerola BRS 238. Different letters represent signficant difference by $5 \%$.

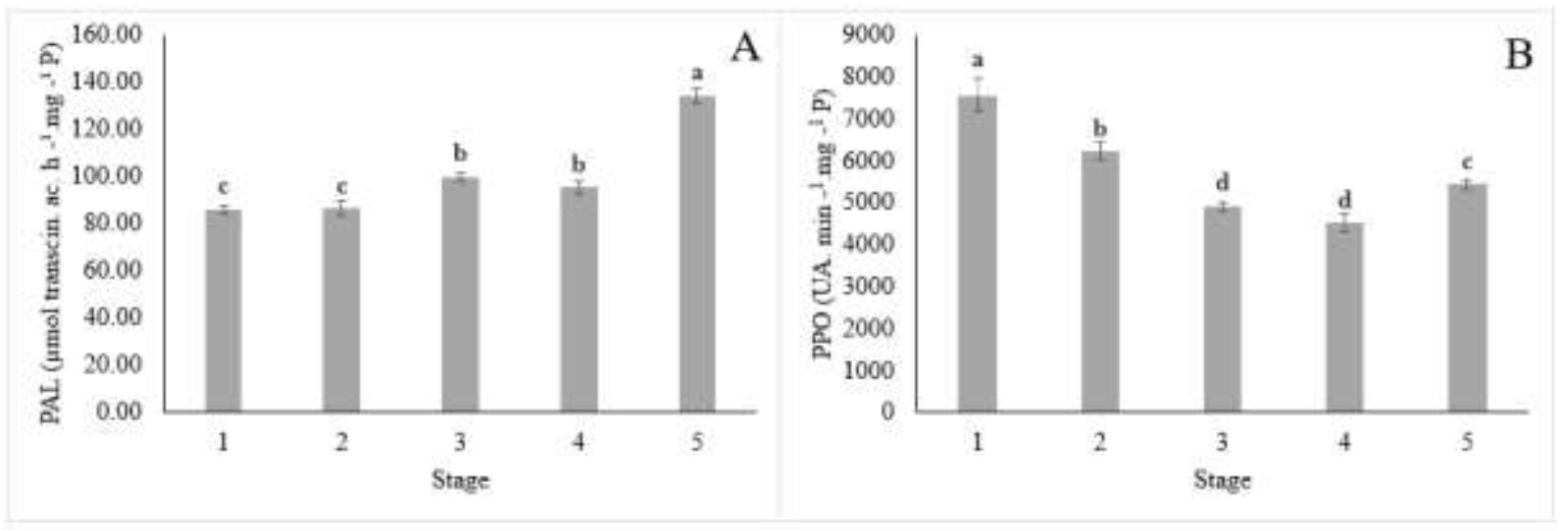

Source: Authors (2020).

PPO phenolic-degradative activity declined from 7,559.52 AU min- ${ }^{1} \cdot \mathrm{mg}^{-1} \mathrm{P}$, at stage 1 to $5,438.65 \mathrm{AU}$ min- ${ }^{1} \cdot \mathrm{mg}^{-1} \mathrm{P}$, at stage 5 (Figure 10B). PPO is located in plastids, while its substrates, phenolic compounds are in vacuoles and from the moment there is some type of damage to the plant tissue, decompartmentalization occurs and this enzyme comes into contact with its substrate (Murata, Noda , \& Homma, 1995; Parkin, 2010; Liu et al., 2011). When the enzyme meets its substrate, oxidation reactions that form quinones generally occur, leading to non-enzymatic reactions that polymerize and give rise to dark colored pigments (melanins) (Zeraik, Souza, Fatibello -Son, \& Leite, 2008). The action of this enzyme causes loss of quality and changes the flavor, in addition to cause enormous economic losses (Araujo, 2004).

\section{Conclusions}

It can be concluded that acerola BRS 238 (Frutacor) has a high SS/AT ratio that gives a sweeter flavor to this fruit compared to other clones, and ripening led to decrease in vitamin $\mathrm{C}$ and polyphenols content due the activity of enzymes of their respective metabolism. Although these compounds decrease their content in the final stages of development, there are still found in considerably high content. Thus, for vitamin $\mathrm{C}$ industrial extraction, fruit should be harvested at stage 1, while fresh fruit marketing of the fruit, stages 4 and 5 are the most recommended.

In future studies that address the subject, it is suggested that a deeper study be done on the enzymes that are part of vitamin C metabolism, specifically the activity of the enzymes L-galactone-1,4-lactone dehydrogenase, Monodehydroascorbate reductase, Dehydroascorbate reductase and Glutathione reductase since they are part of the recycling of this vitamin in the plant and directly interfere in its metabolism. With these it would be possible to better discuss the results seen in this work.

\section{Acknowledgment}

National Council for Scientific and Technological Development (CNPq), INCT Tropical Fruits and Coordination for the Improvement of Higher Education Personnel (CAPES). 


\section{References}

Alamed, J., Chaiyasit, W., McClements, D. J., \& Decker, E. A. (2009). Relationships between free radical scavenging and antioxidant activity in foods. Journal of agricultural and food chemistry, 57(7), 2969-2976.

Almeida, S. D. S., Alves, W. A. L., Araújo, S. A. D., Santana, J. C. C., Narain, N., \& Souza, R. R. D. (2014). Use of simulated annealing in standardization and optimization of the acerola wine production. Food Science and Technology, 34(2), 292-297.

Anuário da agricultura brasileira. São Paulo: Instituto FNP, p. 448, 2019.

Araújo, J. (2004). Química de alimentos: teoria e prática. In Química de alimentos: teoria e prática (pp. 478-478).

Association of Official Analytical Chemistry. (2005). Official methods of Analysis of the Association of Official Analytical Chemistry. (18th ed.), Maryland: AOAC.

Batista, P. F., Lima, M. A. C. D., Alves, R. E., \& Façanha, R. V. (2018). Bioactive compounds and antioxidant activity in tropical fruits grown in the lowermiddle São Francisco Valley. Revista Ciência Agronômica, 49(4), 616-623.

Bergmeyer, H. U. (1974). Methods of enzymatic analysis. Verlag Chemie.

Bradford, M. M. (1976). A rapid and sensitive method for the quantitation of microgram quantities of protein utilizing the principle of protein-dye binding. Analytical biochemistry, 72(1-2), 248-254.

Calgaro, M.; Braga, M. (2012). Coleção Plantar: acerola. Brasília, DF, 150 p.

Cardello, H. M. A., \& Cardello, L. (1998). Teor de vitamina C, atividade de ascorbato oxidase e perfil sensorial de manga (Mangifera indica L.) var. Haden, durante o amadurecimento. Food Science and Technology, 18(2), 211-217.

Chen, J.; Wang, X. Experimental instruction of plant physiology. (2002). South China University of Technology Press, 1(3), 124.

Delgado-Vargas, F., Jiménez, A. R., \& Paredes-López, O. (2000). Natural pigments: carotenoids, anthocyanins, and betalains-characteristics, biosynthesis, processing, and stability. Critical reviews in food science and nutrition, 40(3), 173-289.

Delva, L., \& Schneider, R. G. (2013). Acerola (Malpighia emarginata DC): production, postharvest handling, nutrition, and biological activity. Food Reviews International, 29(2), 107-126.

El-Shora, H. M. (2002). Properties of phenylalanine ammonia-lyase from marrow cotyledons. Plant Science, 162(1), 1-7.

Figueiredo Neto, A., Reis, D., Alves, E., Gonçalves, E., Anjos, F. D., \& Ferreira, M. (2014). Determinação de vitamina c e avaliação físico-química em três variedades de acerola cultivadas em Petrolina-PE. Nucleus, 11(1), 83-92.

Foti, M., Piattelli, M., Amico, V., \& Ruberto, G. (1994). Antioxidant activity of phenolic meroditerpenoids from marine algae. Journal of Photochemistry and Photobiology B: Biology, 26(2), 159-164.

Foyer, C. H., \& Noctor, G. (2011). Ascorbate and glutathione: the heart of the redox hub. Plant physiology, 155(1), 2-18.

Francis, F. J. (1982). Analysis of anthocyanins. Anthocyanins as food colors, 1, 280.

Gomez, M. L. P., \& Lajolo, F. M. (2008). Ascorbic acid metabolism in fruits: activity of enzymes involved in synthesis and degradation during ripening in mango and guava. Journal of the Science of Food and Agriculture, 88(5), 756-762.

Huber, L. S., \& Rodriguez-Amaya, D. B. (2008). Flavonóis e flavonas: fontes brasileiras e fatores que influenciam a composição em alimentos. Alimentos $e$ Nutrição, Araraquara, 19(1), 97-108.

Instituto Adolfo Lutz. (1985). Normas analíticas, métodos químicos e físicos para análises de alimentos, 1, (3rd ed.).

Instituto Brasileiro de Geografia e Estatística. SIDRA: levantamento sistemático da produção agrícola. Rio de Janeiro, 2018.

Larrauri, J. A., Rupérez, P., \& Saura-Calixto, F. (1997). Effect of drying temperature on the stability of polyphenols and antioxidant activity of red grape pomace peels. Journal of agricultural and food chemistry, 45(4), 1390-1393.

Lilchtenthaler, H. K., \& Wellburn, A. R. (1983). Determinations of total carotenoids and chlorophylls a and b of leaf extracts in different solvents. Journal Agricola Food Chemistry, Milão, v. 45, p. 1390-1393.

Lima, V. L., Mélo, E. A., Maciel, M. I. S., Prazeres, F. G., Musser, R. S., \& Lima, D. E. (2005). Total phenolic and carotenoid contents in acerola genotypes harvested at three ripening stages. Food chemistry, 90(4), 565-568.

Liu, H., Song, L., You, Y., Li, Y., Duan, X., Jiang, Y., Joice, D. C., Ashraf, M., \& Lu, W. (2011). Cold storage duration affects litchi fruit quality, membrane permeability, enzyme activities and energy charge during shelf time at ambient temperature. Postharvest Biology and Technology, 60(1), 24-30.

Maciel, M. I. S., Mélo, E., Lima, V., Souza, K. A., \& Silva, W. (2010). Caracterização físico-química de frutos de genótipos de aceroleira (Malpighia emarginata DC). Food Science and Technology, 30(4), 865-869.

Mariano-Nasser, F. D. C., Nasser, M. D., Furlaneto, K. A., Ramos, J. A., Vieites, R. L., \& Pagliarini, M. K. (2017). Bioactive compounds in different acerola fruit cultivares. Semina: Ciências Agrárias (Londrina), 38(4 Suppl. 1), 2505-2514. 
Moreira, G. E. G., Costa, M. G. M., de Souza, A. C. R., de Brito, E. S., de Medeiros, M. D. F. D., \& de Azeredo, H. M. (2009). Physical properties of spray dried acerola pomace extract as affected by temperature and drying aids. LWT-Food Science and Technology, 42(2), 641-645.

Mori, T., Sakurai, M., \& Sakuta, M. (2001). Effects of conditioned medium on activities of PAL, CHS, DAHP synthase (DS-Co and DS-Mn) and anthocyanin production in suspension cultures of Fragaria ananassa. Plant Science, 160(2), 355-360.

Moura, C., de Aragão, F. A. S., Oliveira, L. D. S., Moreira, S., \& de Miranda, M. R. A. (2012). Qualidade pós-colheita durante o amadurecimento de frutos de clones de aceroleira. Embrapa Agroindústria Tropical-Boletim de Pesquisa e Desenvolvimento (INFOTECA-E).

Murata, M., Noda, I., Homma, S. (1995). Enzymatic browning of apples on the market: relationship between browning, polyphenol content, and polyphenol oxidase. Hort Science, 42(10), 820-826.

Nakano, Y., \& Asada, K. (1981). Hydrogen peroxide is scavenged by ascorbate-specific peroxidase in spinach chloroplasts. Plant and cell physiology, 22(5), $867-880$.

Nasser, M. D., \& Zonta, A. (2014). Caracterização de frutos de genótipos de aceroleira em função de estádios de maturação. Tecnologia \& Ciência Agropecuária, João Pessoa, 8(5), 76-78.

Nasser, M. D., de Carvalho Mariano-Nasser, F. A., Furlaneto, K. A., Ramos, J. A., \& Caetano, P. K. (2018). Composição da acerola de diferentes genótipos em duas épocas de colheita. Nativa, 6(1), 15-19.

Obanda, M., Owuor, P. O., \& Taylor, S. J. (1997). Flavanol composition and caffeine content of green leaf as quality potential indicators of Kenyan black teas. Journal of the Science of Food and Agriculture, 74(2), 209-215.

Oliveira, L. D. S. (2012). Avaliação do metabolismo antioxidante durante o desenvolvimento de frutos de clones de aceroleira e sapotizeiro.

Oliveira, L. M. N., da Silva, L. M. R., de Lima, A. C. S., de Almeida, R. R., Ricardo, N. M. P. S., de Figueiredo, E. A. T., \& de Figueiredo, R. W. (2020). Characterization of rutin, phenolic compounds and antioxidant capacity of pulps and by-products of tropical fruits. Research, Society and Development, 9(4), 42942812.

Oliveira, L. S., Rufino, M. S., Moura, C. F., Cavalcanti, F. R., Alves, R. E., \& Miranda, M. R. (2011). The influence of processing and long-term storage on the antioxidant metabolism of acerola (Malpighia emarginata) purée. Brazilian Journal of Plant Physiology, 23(2), 151-160.

Parkin, K. L. Enzimas. In.: Damodaran, S.; Parkin, K.; Fennema, O.R. Química de Alimentos de Fennema. (4th ed.), Artmed, 2010. 900 p.

Rabelo, M. C. (2016). Efeitos da luz pulsada sobre o metabolismo de vitamina ce compostos fenólicos em acerola (Malpighia emarginata DC).

Ribeiro, B. S., \& de Freitas, S. T. (2020). Maturity stage at harvest and storage temperature to maintain postharvest quality of acerola fruit. Scientia Horticulturae, 260, 108901.

Rice-evans, C. A., Miller, N. J., Bolwell, P. G., Bramley, P. M., \& Pridham, J. B. (1995). The relative antioxidant activities of plant-derived polyphenolic flavonoids. Free radical research, 22(4), 375-383.

Righetto, A. M., Netto, F. M., \& Carraro, F. (2005). Chemical composition and antioxidant activity of juices from mature and immature acerola (Malpighia emarginata DC). Food science and technology international, 11(4), 315-321.

Ritzinger, R., \& Ritzinger, C. H. S. P. (2011). Acerola. Embrapa Mandioca e Fruticultura-Artigo em periódico indexado (ALICE).

Ritzinger, R., Ritzinger, C. H. S. P., Fonseca, N., \& Machado, C. D. F. (2018). Avanços na propagação da aceroleira. Revista Brasileira de Fruticultura, 40(3).

Rufino, M. D. S. M., Alves, R. E., de Brito, E. S., de Morais, S. M., Sampaio, C. D. G., Pérez-Jimenez, J., \& Saura-Calixto, F. D. (2007). Metodologia científica: determinação da atividade antioxidante total em frutas pela captura do radical livre DPPH. Embrapa Agroindústria Tropical-Comunicado Técnico (INFOTECA-E).

Santos, S. M., De Vasconcelos, A. M., Oliveira, V. S., Clemente, E., \& Costa, J. M. (2012). Evaluation of physical and physicochemical characteristics of Malpighia emarginata DC from the state of Ceará. International Journal of Biochemistry Research \& Review, 2(4), 152.

Sojo, M. M., Nunez-Delicado, E., García-Carmona, F., \& Sánchez-Ferrer, A. (1998). Partial purification of a banana polyphenol oxidase using Triton X-114 and PEG 8000 for removal of polyphenols. Journal of Agricultural and Food Chemistry, 46(12), 4924-4930.

Souza, K. O. D. (2012). Qualidade e metabolismo antioxidante no desenvolvimento de frutos de clones de aceroleira.

Souza, K. O., Moura, C. F. H., Brito, E. S., Miranda, M. R. A. (2014). Antioxidant compounds and total antioxidant activity in fruits of acerola from cv. Flor Branca, Florida Sweet and BRS 366. Revista Brasileira de Fruticultura, 36(2), 294-304.

Uenojo, M., Maróstica Junior, M. R., \& Pastore, G. M. (2007). Carotenóides: propriedades, aplicações e biotransformação para formação de compostos de aroma. Química Nova, 30(3), 616-622.

Vendramini, A. L., \& Trugo, L. C. (2000). Chemical composition of acerola fruit (Malpighia punicifolia L.) at three stages of maturity. Food Chemistry, 71(2), 195-198.

Viana, E. D. S., Reis, R., Ritzinger, R., de Jesus, J. L., Santos Júnior, R. D. S., \& Cordeiro, Z. (2017). Caracterização físico-química e de compostos bioativos de acerola orgânica. Embrapa Mandioca e Fruticultura-Boletim de Pesquisa e Desenvolvimento (INFOTECA-E).

Yan, S., Li, L., He, L., Liang, L., \& Li, X. (2013). Maturity and cooling rate affects browning, polyphenol oxidase activity and gene expression of 'Yali'pears during storage. Postharvest Biology and Technology, 85, 39-44. 
Research, Society and Development, v. 10, n. 2, e42410212640, 2021

(CC BY 4.0) | ISSN 2525-3409 | DOI: http://dx.doi.org/10.33448/rsd-v10i2.12640

Yang, Z., Zheng, Y., \& Cao, S. (2009). Effect of high oxygen atmosphere storage on quality, antioxidant enzymes, and DPPH-radical scavenging activity of Chinese bayberry fruit. Journal of agricultural and food chemistry, 57(1), 176-181.

Zeraik, A. E., Souza, F. S. A. D., Fatibello-Filho, O., \& Leite, O. D. (2008). Desenvolvimento de um spot test para o monitoramento da atividade da peroxidase em um procedimento de purificação. Química Nova, 31(4), 731-734.

Zimmermann, P. E. T. R. A., \& Zentgraf, U. L. R. I. K. E. (2005). The correlation between oxidative stress and leaf senescence during plant development. Cellular and Molecular Biology Letters, 10(3), 515. 